\title{
The effect of $p H$ on the simultaneous determination of Sulfamethoxazole and Trimethoprim by Ultraviolet Spectrophotometry and Multivariate Calibration
}

\author{
Fabiana EB da Silva ${ }^{\mathrm{a} *}$, Willian RR Almeida ${ }^{\mathrm{a}}$, Fávero R Paula ${ }^{\mathrm{a}}$, Aline LH Müller ${ }^{\mathrm{b}}$, \\ Érico MM Flores ${ }^{\mathrm{b}}$ and Marco F Ferrão ${ }^{\mathrm{c}}$ \\ ${ }^{a}$ Curso de Farmácia, Universidade Federal do Pampa (UNIPAMPA) - Campus Uruguaiana. RS, Brasil. \\ ${ }^{\mathrm{b}}$ Departamento de Química, Universidade Federal de Santa Maria (UFSM). RS, Brasil. \\ 'Instituto de Química, Universidade Federal do Rio Grande do Sul (UFRGS). RS, Brasil \\ Corresponding author e-mail: fabianasilva@unipampa.edu.br
}

\begin{abstract}
Analytical techniques based on Ultraviolet (UV) spectrophotometry are widely used in pharmaceutical analysis, because they are simple and inexpensive. The choice of $\mathrm{pH}$ is critical in the development of univariate methods for pharmaceutical quantitation by UV spectrophotometry since changes may modify the absorption spectrum profile. Similar to univariate methods by UV spectrophotometry changes in $\mathrm{pH}$ may influence the predictive ability of multivariate models, affecting the resultant analytical performance. We report herein on the influence of $\mathrm{pH}$ on the simultaneous determination of sulfamethoxazole (SMZ) and trimethoprim (TMP) in tablets using UV spectrophotometry and multivariate calibration. Data were recorded using a UV spectrophotometer in the wavelength range of 200 to $350 \mathrm{~nm}$. The experimental matrix was constructed using 36 synthetic samples of SMZ-TMP mixtures. The concentration ranges used for the investigation were 14.0 to $26.0 \mathrm{mg} \mathrm{L}^{-1}$ for SMZ and 2.8 to $5.2 \mathrm{mg} \mathrm{L}^{-1}$ for TMP. The Partial Least Squares (PLS) regression models were generated with full-spectrum and multiple $\mathrm{pH}$ levels. At $\mathrm{pH} 4.3$, lower values of relative standard error of prediction (RSEP $\%$ ) for SMZ (1.83) and TMP (1.13) were obtained. The PLS model at $\mathrm{pH} 4.3$ was used for the quantification of real samples (tablets obtained from 13 different manufacturers) and the results were compared with conventional procedures using high performance liquid chromatography (HPLC).
\end{abstract}

Keywords: chemometrics, sulphamethoxazole, trimethoprim, ultraviolet.

\section{Introduction}

Sulfamethoxazole (SMZ) is a synthetic antibacterial drug belonging to the sulfonamides, which is similar in structure to $\mathrm{p}$ aminobenzoic acid, and inhibits the incorporation of p-aminobenzoic acid into folic acid. Association of SMZ with trimethoprim (TMP) results in a synergistic effect, since TMP acts via inhibition of dihydrofolate reductase (1). This synergistic effect induces potent antimicrobial activity because SMZ-TMP acts on different stages of bacterial DNA synthesis. Pharmaceutical formulations containing SMZTMP are commercially available in tablet form and in parenteral solutions. The chemical structures of SMZ (A) and TMP (B) are showed in Figure 1.

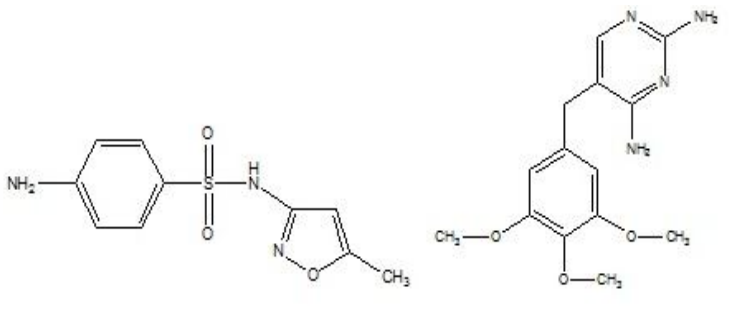

Figure 1 Chemical structure of SMZ (A) and TMP (B)

Official monographs for SMZ-TMP quantification in pharmaceutical preparation have been described using high performance liquid chromatography (HPLC) and spectrophotometric methods, which involve pre-separation of the analytes under investigation $(2,3)$. Several other methods have also been reported for SMZ-TMP determination based on: (a) complexation reactions/spectrophotometric analysis (4), first derivative spectrophotometric analysis (5), bivariate calibration (6) and multivariate 
calibration (7-9). These alternative methods could replace those based on HPLC since they are faster and comparatively inexpensive (1014). Nevertheless, alternative methods using ultraviolet (UV) spectrophotometric techniques require multivariate data processing due to spectral overlap and $\mathrm{pH}$ adjustment due to a shift in the lambda maximum.

Multivariate data processing using partial least squares (PLS) regression models has been used in association with UV spectrophotometric methods for the simultaneous determination of pharmaceutical formulations, especially in cases of spectral overlap resolution (15-18). However, for spectroscopic data produced by multivariate regression analysis, few studies have been reported that evaluate $\mathrm{pH}$ changes that may exert significant influence on PLS models, mainly because of possible protonation equilibria. For simultaneous determination of SMZ (a weak acid) and TMP (a weak base) using UV spectrophotometry, shifts caused by changes in $\mathrm{pH}$ can compromise the predictive ability of multivariate models. Hence, this body of work reports on the influence of $\mathrm{pH}$ on the predictive ability of multivariate models (PLS regression) for the simultaneous determination of SMZ-TMP using a UV spectrophotometric method.

\section{Experimental}

\section{Chemicals}

Certified reference sulphamethoxazole (SMZ RS) and trimethoprim (TMP RS) materials were acquired from the Brazilian Pharmacopoeia (batches 1010 and 1011 for SMZ and TMP, respectively). The SMZ (batch 22960805) and TMP (batch 200504246) bulk drugs were purchased from Henrifarma (Sao Paulo, Brazil) and were used for the preparation of synthetic samples. SMZ RS, TMP RS, SMZ bulk drug and TMP bulk drug showed purity in accordance with Brazilian Pharmacopoeia monographs (99-101\% SMZ and 98.5-101\% TMP). Methanol, acetonitrile and triethylamine were of HPLC grade. Thirteen commercial tablet formulations (named commercial samples) were acquired in local drugstores or were donated by pharmaceutical industries. Phosphate buffer (PB) solutions ( $\mathrm{pH}$ 4.3-7.8) were prepared in accordance with the Brazilian Pharmacopoeia (2).

\section{Chromatographic system and conditions}

Determination of SMZ and TMP content was carried out using HPLC according to the method described in the United States Pharmacopoeia (3). This procedure was chosen as the reference and it was performed with a HPLC system consisting of an Agilent 1100 Series system equipped with a pump (model G1311A), a detector (model G1315B DAD) and an automatic sampling system (model G133A ALS). The detector was set at $254 \mathrm{~nm}$ and the peak areas were integrated automatically using a Chemstation ${ }^{\circledR}$ computer software program (Agilent Technologies Inc., California, USA). The separations were carried out at ambient temperature using a Zorbax ${ }^{\circledR}$ SBC-18 column ( $250 \mathrm{~mm} \times 4.5 \mathrm{~mm}$ i.d., $5 \mu \mathrm{m}$ particle size). A Zorbax ${ }^{\circledR}$ SBC-18 column (12.5 $\mathrm{mm}$ x $4.5 \mathrm{~mm}$ i.d., $5 \mu \mathrm{m}$ particle size) guard cartridge system was used to safeguard the analytical column. The mobile phase was a mixture of water: acetonitrile: triethylamine $(1400: 400: 2, \mathrm{v} / \mathrm{v} / \mathrm{v})$. The $\mathrm{pH}$ was adjusted to 5.9 and the volume $(2000 \mathrm{~mL})$ was completed with ultrapurified water. Commercial tablets were finely crushed to a fine powder and mixed. A mass corresponding to $160 \mathrm{mg}$ of SMZ and 32 mg TMP for each commercial formulation was accurately weighed and dissolved in $100 \mathrm{~mL}$ of methanol. Dissolution was carried out with the aid of an ultrasonic bath $(15 \mathrm{~min}$.) A $5 \mathrm{~mL}$ aliquot of each sample was added to $50 \mathrm{~mL}$ volumetric flasks and the mobile phase was used to complete the volume $\left(\mathrm{SMZ}_{\text {work solution }}=\right.$ $160 \mu \mathrm{g} \mathrm{mL}^{-1}$; $\left.\mathrm{TMP}_{\text {work solution }}=32 \mu \mathrm{g} \mathrm{mL}^{-1}\right)$. All of analyses were performed in triplicate.

\section{Spectrophotometric system and conditions}

Spectrophotometric measurements were recording using a Shimadzu 1800 spectrophotometer. All spectra were recorded 
from $200 \mathrm{~nm}$ to $350 \mathrm{~nm}$ using quartz cuvettes with a $1 \mathrm{~cm}$ optical path. Thirty-six solutions containing SMZ-TMP were prepared in PB at each $\mathrm{pH}(4.3,5.8,6.6$ and 7.8). From this series, 22 solutions were chosen for the calibration set according to the mixture design for two component systems, and 14 solutions (chosen randomly) were used in the prediction set (Table 1). SMZ-TMP chemical species at different $\mathrm{pKa}$ values were calculated using MarvinSketch software, version 6.2.1 (ChemAxon, USA). Commercial tablets were finely crushed to a fine powder and mixed. A mass corresponding to $100 \mathrm{mg}$ of SMZ and 20 mg of TMP for each commercial formulation was accurately weighed and dissolved in 100 $\mathrm{mL}$ of methanol. Dissolution was carried out with the aid of an ultrasonic bath (15 min.) A 1 $\mathrm{mL}$ aliquot of each sample was added to $50 \mathrm{~mL}$ volumetric flasks and $\mathrm{PB}$ at $\mathrm{pH} 4.3$ was used to complete the volume $\left(\mathrm{SMZ}_{\text {work solution }}=20 \mu \mathrm{g}\right.$ $\mathrm{mL}^{-1}$; TMP work solution $=4 \mu \mathrm{g} \mathrm{mL} \mathrm{m}^{-1}$ ). All of analyses were performed in triplicate for both the synthetic and the commercial samples.

Table 1 Calibration and prediction set for SMZ-TMP solutions

\begin{tabular}{|c|c|c|}
\hline Samples & $\operatorname{SMZ}\left(\mu \mathrm{g} \mathrm{mL}^{-1}\right)$ & $\operatorname{TMP}\left(\mu \mathrm{g} \mathrm{mL}^{-1}\right)$ \\
\hline $1^{\mathrm{C}}$ & 14.0 & 2.8 \\
\hline $2^{c}$ & 15.5 & 2.8 \\
\hline $3^{p}$ & 18.5 & 2.8 \\
\hline $4^{\mathrm{C}}$ & 21.5 & 2.8 \\
\hline $5^{p}$ & 24.5 & 2.8 \\
\hline $6^{\mathrm{c}}$ & 26.0 & 2.8 \\
\hline $7^{p}$ & 14.0 & 3.1 \\
\hline $8^{p}$ & 15.5 & 3.1 \\
\hline $9 \mathrm{p}$ & 18.5 & 3.1 \\
\hline $10^{p}$ & 21.5 & 3.1 \\
\hline $11^{\mathrm{C}}$ & 24.5 & 3.1 \\
\hline $12^{\mathrm{p}}$ & 26.0 & 3.1 \\
\hline $13^{p}$ & 14.0 & 3.7 \\
\hline $14^{\mathrm{C}}$ & 15.5 & 3.7 \\
\hline $15^{\mathrm{C}}$ & 18.5 & 3.7 \\
\hline $16^{\mathrm{C}}$ & 21.5 & 3.7 \\
\hline $17^{\mathrm{P}}$ & 24.5 & 3.7 \\
\hline $18^{\mathrm{C}}$ & 26.0 & 3.7 \\
\hline $19^{\mathrm{C}}$ & 14.0 & 4.3 \\
\hline $20^{\mathrm{C}}$ & 15.5 & 4.3 \\
\hline $21^{\mathrm{C}}$ & 18.5 & 4.3 \\
\hline $22^{\mathrm{C}}$ & 21.5 & 4.3 \\
\hline $23^{\mathrm{C}}$ & 24.5 & 4.3 \\
\hline $24^{\mathrm{C}}$ & 26.0 & 4.3 \\
\hline $25^{\mathrm{C}}$ & 14.0 & 4.9 \\
\hline
\end{tabular}

\begin{tabular}{lll}
\hline $26^{\mathrm{p}}$ & 15.5 & 4.9 \\
$27^{\mathrm{p}}$ & 18.5 & 4.9 \\
$28^{\mathrm{p}}$ & 21.5 & 4.9 \\
$29^{\mathrm{p}}$ & 24.5 & 4.9 \\
$30^{\mathrm{C}}$ & 26.0 & 4.9 \\
$31^{\mathrm{p}}$ & 14.0 & 5.2 \\
$32^{\mathrm{C}}$ & 15.5 & 5.2 \\
$33^{\mathrm{C}}$ & 18.5 & 5.2 \\
$34^{\mathrm{C}}$ & 21.5 & 5.2 \\
$35^{\mathrm{C}}$ & 24.5 & 5.2 \\
$36^{\mathrm{p}}$ & 26.0 & 5.2 \\
\hline
\end{tabular}

\section{Multivariate calibration}

Data were handled using Unscrambler $\mathrm{X}^{\circledR}$ software (CAMO, USA). The spectra of samples were preprocessed by multiplicative scatter correction (MSC), autoscalling (A) and mean centering (MC). A statistical $F$-test $(\alpha=0.5 \%)$ was introduced to evaluate if there were significant differences between the prediction errors of constructed models under different preprocessing conditions. PLS models were constructed at different $\mathrm{pH}$ values and the root mean squares error of cross-validation (RMSECV) was used to select the number of latent variables $(\mathrm{LV})$. The root mean square error of calibration (RMSEC) and the root mean square error of prediction (RMSEP) were used to evaluate the prediction ability of different PLS models. The performance of the calibration models obtained was checked by the relative standard error of prediction (RSEP \%) (8). The PLS model than presented the minor RMSEP value was selected for quantification of the commercial samples.

\section{Results and Discussion}

\section{SMZ-TMP chemical species}

Theoretical values of $\mathrm{pKa}$ and chemical species were calculated from a $0-14 \mathrm{pH}$ range in order to identify the protonation states of SMZ and TMP. SMZ (considered a weak acid) showed four ionized forms and one neutral form as presented in Figure 2 (4). 


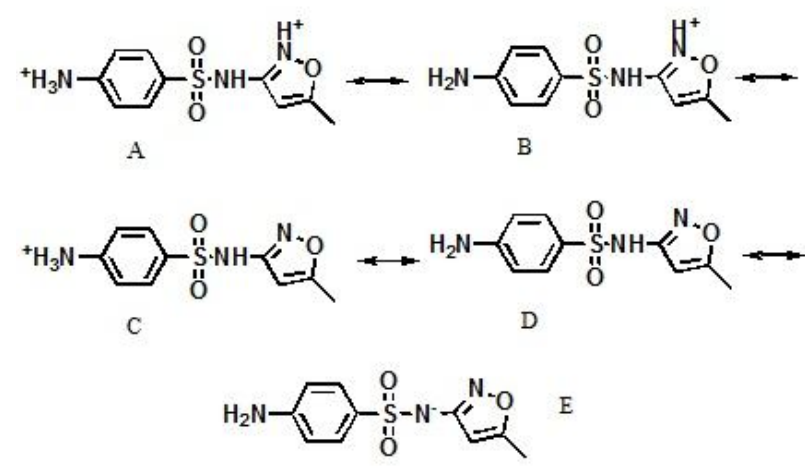

Figure 2 Chemical species of SMZ (A-E) in the $0-4 \mathrm{pH}$ range (calculated by Marvin Sketch software).

TMP (considered a weak base) showed three ionized forms and one neutral form as presented in Figure 3 (19).

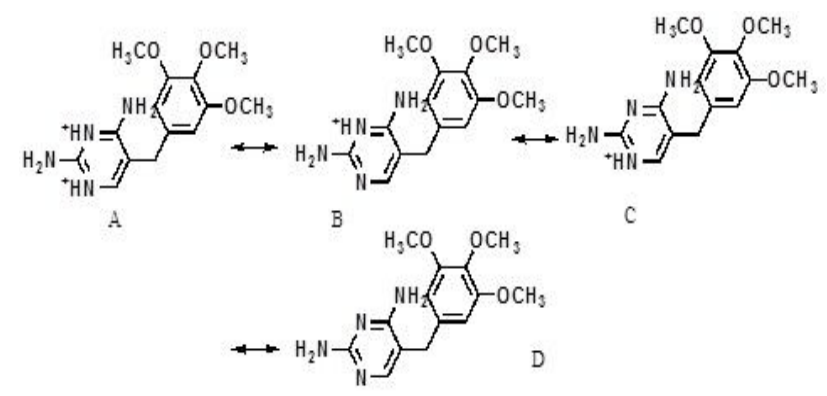

Figure 3 Chemical species of TMP (A-D) in the $0-14 \mathrm{pH}$ range (calculated by MarvinSketch software).

Depending on the $\mathrm{pH}$, chemical structures with protonatable groups may show shifts or alterations in signal intensity in UV spectra depending on the proximity of the ionizable groups and the chromophores (20). According to the data presented in table 2 , the neutral form (D) of SMZ is predominant in solution prepared with $\mathrm{pH}$ 4.3 PB. For TMP, the ionized form (C) is predominant in solutions prepared with $\mathrm{pH}$ 4.3 and $\mathrm{pH} 5.8 \mathrm{~PB}$.

\begin{tabular}{|c|c|c|c|c|c|}
\hline \multirow[t]{3}{*}{$\mathrm{pH}$} & \multicolumn{5}{|c|}{ Chemical species (\%) } \\
\hline & \multicolumn{5}{|c|}{ SMZ } \\
\hline & A & B & $\mathrm{C}$ & $\mathrm{D}$ & E \\
\hline 4.3 & 0.36 & 0.00 & 0.00 & 97.92 & 1.70 \\
\hline 5.8 & 0.00 & 0.00 & 0.00 & 69.63 & 30.25 \\
\hline 6.6 & 0.00 & 0.00 & 0.00 & 18.66 & 81.34 \\
\hline \multirow[t]{3}{*}{7.8} & 0.00 & 0.00 & 0.00 & 2.24 & 97.76 \\
\hline & \multicolumn{5}{|c|}{ TMP } \\
\hline & A & B & $\mathrm{c}$ & $\mathrm{D}$ & - \\
\hline 4.3 & 0.00 & 0.39 & 95.43 & 0.11 & - \\
\hline 5.8 & 0.00 & 0.37 & 95.41 & 4.22 & - \\
\hline 6.6 & 0.00 & 0.31 & 77.96 & 21.74 & - \\
\hline 7.8 & 0.00 & 0.07 & 18.44 & 81.49 & \\
\hline
\end{tabular}

According to the literature, the UV absorption spectra of SMZ show a lambda-max at $260 \mathrm{~nm}$ and TMP exhibits a UV lambda-max at $215 \mathrm{~nm}$ (7). In UV absorption spectra collected from a mixture containing SMZ-TMP (14 $\mu \mathrm{g} \mathrm{mL}^{-1}$ and $2.8 \mu \mathrm{g} \mathrm{mL}^{-1}$, respectively), at different $\mathrm{pH}$ values, it is possible to observe shifts resulting from the ionization of the pharmaceuticals (Figure 4). At approximately $260 \mathrm{~nm}$ hypsochromic and hiperchromic effects can be observed as the $\mathrm{pH}$ increases, which is typical for spectra of SMZ. The hypochromic effect at $215 \mathrm{~nm}$ (characteristic of TMP) was only observed for solutions prepared in $\mathrm{pH} 6.6$ and $\mathrm{pH} 7.8 \mathrm{~PB}$. In solutions with lower $\mathrm{pH}$ values (4.3 and 5.8) lambda-max is shifted to values of less than $200 \mathrm{~nm}$. This shift (hypsochromic effect) can be attributed to SMZ (in higher amount in SMZ-TMP solution). According to the literature, shifts can be observed in SMZ-TMP UV spectra acquired from solutions prepared in different conditions of acidity, requiring the use of buffer solutions (19). These shifts in SMZ-TMP spectra, caused by different acidic conditions, can interfere in UV spectrophotometric quantification, especially when information from a full spectrum or parts of a spectrum is used for constructing multivariate calibration models. 


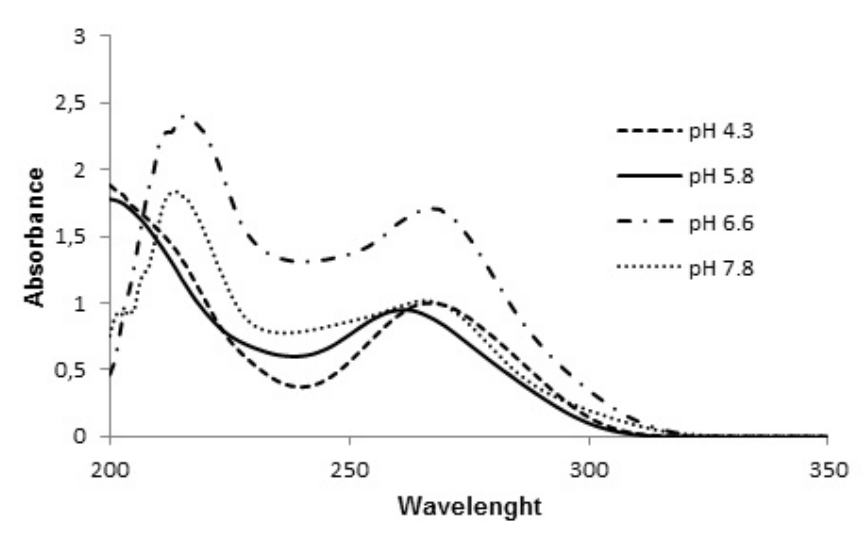

Figure 4 UV spectrum for SMZ-TMP solutions at different $\mathrm{pH}$ values.

PLS regression models were developed for samples prepared under different $\mathrm{pH}$ conditions by using preprocessing AUTO. LV, RMSEC, RMSEP and $R_{\text {cal }^{2}}$ are shown in Table 3.

\begin{tabular}{|c|c|c|c|c|}
\hline $\mathrm{pH}$ & $\mathrm{LV}^{*}$ & $\begin{array}{l}\text { RMSEC } \\
\left(\mu \mathrm{g} \mathrm{mL}^{-1}\right)\end{array}$ & $\begin{array}{l}\text { RMSEP } \\
\left(\mu \mathrm{g} \mathrm{mL}^{-1}\right)\end{array}$ & $\mathrm{R}_{\mathrm{cal}}{ }^{2 * *}$ \\
\hline 4.3 & 3 & 0.3997 & 0.3775 & 0.9915 \\
\hline 5.8 & 3 & 0.5237 & 0.4558 & 0.9855 \\
\hline 6.6 & 4 & 1.6802 & 1.1984 & 0.8550 \\
\hline 7.8 & 3 & 0.6665 & 0.7505 & 0.9763 \\
\hline
\end{tabular}

The SMZ PLS model with the lowest error was developed using $\mathrm{pH} 4.3$ phosphate buffer solvent. Under these $\mathrm{pH}$ conditions, SMZ exists predominantly in its neutral form (D) and the PLS model was in good agreement with the reference values, i.e. the model showed good predicting ability $(\mathrm{RSEP}=1.83 \%)$. Figure 5 shows the reference values versus the predicted values for the calibration and validation sets.

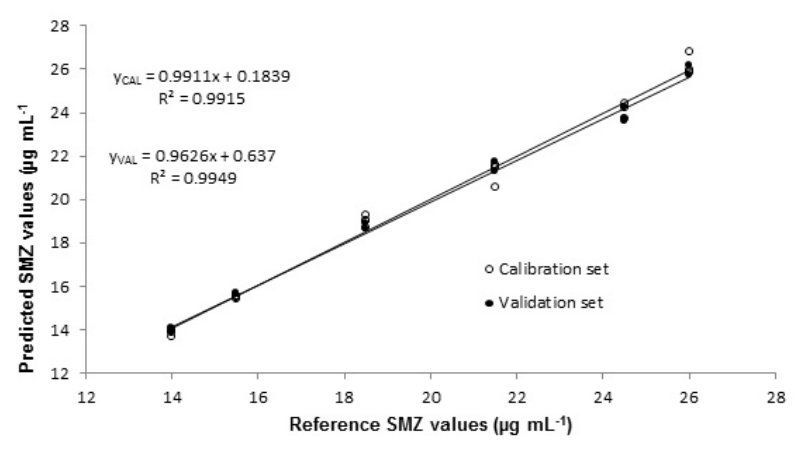

Figure 5 SMZ reference values vs. SMZ predicted values for PLS model at $\mathrm{pH}$ 4.3 .

\section{Trimethoprim PLS models}

PLS regression models were developed for samples prepared under different $\mathrm{pH}$ conditions by using preprocessing AUTO. LV, RMSEC, RMSEP and $R_{\text {cal }^{2}}$ are shown in Table 4.

Table 4 Statistical results of TMP calibration models from 4.3-5.8 $\mathrm{pH}$.

\begin{tabular}{|c|c|c|c|c|}
\hline $\mathrm{pH}$ & $\mathrm{VL}^{*}$ & $\begin{array}{l}\text { RMSEC } \\
\left(\mu \mathrm{g} \mathrm{mL}^{-1}\right)\end{array}$ & $\begin{array}{l}\text { RMSEP } \\
\left(\mu \mathrm{g} \mathrm{mL}^{-1}\right)\end{array}$ & $\mathrm{R}_{\mathrm{cal}^{2}{ }^{2} * *}$ \\
\hline 4.3 & 4 & 0.0766 & 0.0462 & 0.9918 \\
\hline 5.8 & 4 & 0.1173 & 0.1335 & 0.9807 \\
\hline 6.6 & 5 & 0.2966 & 0.4294 & 0.8775 \\
\hline 7.8 & 5 & 0.1479 & 0.1379 & 0.9713 \\
\hline
\end{tabular}

Similar to SMZ, the TMP PLS model with lowest error was developed using $\mathrm{pH} 4.3$ phosphate buffer solvent. Under these conditions, TMP predominantly exists in an ionized form (C) and the PLS model was in good agreement with the reference values, i.e. the model showed good predicting ability $($ RSEP $=1.13 \%)$. Figure 6 shows the reference values versus the predicted values for the calibration and the validation sets. 


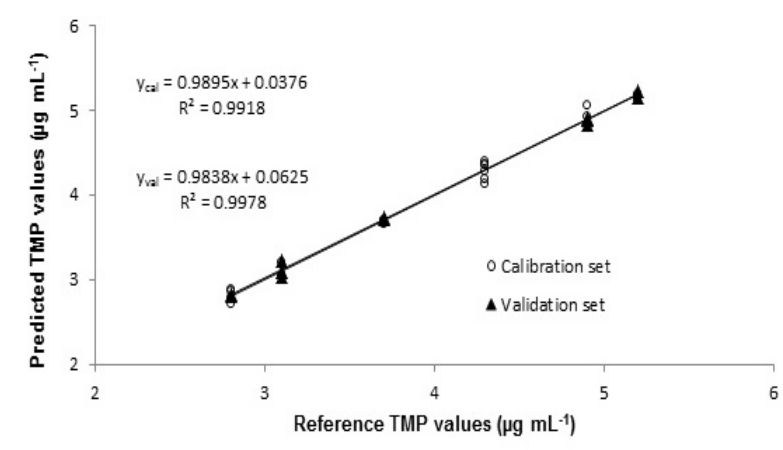

Figure 6 TMP reference values vs. TMP predicted values for PLS model at $\mathrm{pH}$ 4.3.

\section{Sample analysis}

PLS models at $\mathrm{pH} 4.3$ showed an $\mathrm{R}_{\mathrm{cal}}{ }^{2}$ very close to the unity and the lowest RMSEC values, in respect to the models obtained for other $\mathrm{pH}$ values. At this $\mathrm{pH}$, the TMP (in its ionized form, characteristic of weak bases) shows high signal intensity and SMZ (in its neutral form, characteristic of weak acids) shows weak signal intensity when observed in the full spectrum. These two related factors could explain why the model developed for this $\mathrm{pH}$ provides the minor comparative error. Table 5 shows the recovery test for samples of the prediction set. The high recoveries recorded for the sample mixtures highlight the significant promise of the proposed method, in terms of the simultaneous determination of SMZ-TMP at pH 4.3.

Table 5 Recovery test (\%) of prediction set samples.

\begin{tabular}{|c|c|c|c|c|}
\hline & SMZ & & TMP & \\
\hline $\begin{array}{c}\text { Real } \\
\text { Samples }\end{array}$ & HPLC (\%) & UV (\%) & HPLC $(\%)$ & UV (\%) \\
\hline 1 & $103.77 \pm 1.19$ & $99.40 \pm 0.46$ & $98.50 \pm 1.98$ & $100.25=0.90$ \\
\hline 2 & $103.17 \pm 0.74$ & $94.68 \pm 0.69$ & $98.33 \pm 1.69$ & $103.59=1.21$ \\
\hline 3 & $103.70 \pm 1.53$ & $94.10 \pm 1.50$ & $96.83 \pm 0.79$ & $100.25=0.50$ \\
\hline 4 & $103.57 \pm 1.51$ & $104.05 \pm 1.13$ & $104.00 \pm 1.20$ & $96.33 \pm 0.98$ \\
\hline 5 & $98.01 \pm 2.25$ & $95.07 \pm 0.31$ & $98.58 \pm 1.92$ & $105.50 \pm 0.71$ \\
\hline 6 & $103.88 \pm 1.03$ & $101.32 \pm 0.83$ & $99.50 \pm 0.90$ & $105.75 \pm 0.62$ \\
\hline 7 & $98.08 \pm 0.31$ & $94.92 \pm 0.52$ & $100.25 \pm 0.50$ & $100.0=0.75$ \\
\hline 8 & $99.17 \pm 0.73$ & $101.15 \pm 1.43$ & $103.25 \pm 0.87$ & $95.17 \pm 0.55$ \\
\hline 9 & $103.13 \pm 0.88$ & $96.17 \pm 1.11$ & $98.75 \pm 1.01$ & $105.50=0.95$ \\
\hline 10 & $100.83 \pm 2.53$ & $96.07 \pm 0.59$ & $96.92 \pm 0.78$ & $104.42 \pm 0.49$ \\
\hline 11 & $99.88 \pm 0.66$ & $95.40 \pm 0.55$ & $99.33 \pm 0.52$ & $103.67 \pm 1.08$ \\
\hline 12 & $98.33 \pm 0.73$ & $95.48 \pm 0.77$ & $96.25 \pm 1.19$ & $105.17 \pm 0.36$ \\
\hline 13 & $102.70 \pm 0.61$ & $95.62 \pm 0.39$ & $101.33 \pm 0.87$ & $106.08 \pm 0.89$ \\
\hline
\end{tabular}

The PLS models developed at $\mathrm{pH} 4.3$ were used for simultaneous SMZ-TMP quantification in real samples (tablets) from thirteen manufacturers and the values are shown in Table 6. Data were compared with values obtained from HPLC analysis.

\begin{tabular}{|c|c|c|c|c|c|c|}
\hline \multirow[b]{2}{*}{$\begin{array}{c}\text { Sample } \\
\text { Prediction Set }\end{array}$} & \multicolumn{2}{|c|}{$\begin{array}{c}\text { Added }(\mu \mathrm{g} \\
\left.\mathrm{mL}^{-1}\right)\end{array}$} & \multicolumn{2}{|c|}{ Found $\left(\mu \mathrm{g} \mathrm{mL}^{-1}\right)$} & \multicolumn{2}{|c|}{ Recovery $(\%)$} \\
\hline & SMZ & TMP & SMZ & TMP & SMZ & TMP \\
\hline$n^{2} 3$ & 18.5 & 2.8 & 18.91 & 2.83 & 102.22 & 101.064 \\
\hline$n^{\circ} 5$ & 24.5 & 2.8 & 23.74 & 2.81 & 96.89 & 100.39 \\
\hline$n^{2} 7$ & 14.0 & 3.1 & 13.88 & 3.22 & 99.15 & 103.97 \\
\hline$n^{2} 8$ & 15.5 & 3.1 & 15.69 & 3.09 & 101.23 & 99.76 \\
\hline$n^{\circ} 10$ & 21.5 & 3.1 & 21.24 & 3.08 & 98.77 & 99.43 \\
\hline$n^{\circ} 12$ & 26.0 & 3.1 & 26.13 & 3.02 & 100.51 & 97.63 \\
\hline$n^{\circ} 13$ & 14.0 & 3.7 & 13.85 & 3.70 & 98.90 & 100.15 \\
\hline$n^{\circ} 17$ & 24.5 & 3.7 & 23.61 & 3.73 & 96.38 & 100.80 \\
\hline$n^{\circ} 26$ & 15.5 & 4.9 & 15.58 & 4.89 & 100.49 & 99.81 \\
\hline$n^{\circ} 27$ & 18.5 & 4.9 & 18.65 & 4.90 & 100.81 & 99.98 \\
\hline$n^{\circ} 28$ & 21.5 & 4.9 & 21.72 & 4.88 & 101.02 & 99.52 \\
\hline$n^{\circ} 29$ & 24.5 & 4.9 & 24.20 & 4.83 & 98.78 & 98.69 \\
\hline$n^{\circ} 31$ & 14.0 & 5.2 & 14.0872 & 5.22 & 100.62 & 100.36 \\
\hline$n^{\circ} 36$ & 26.0 & 5.2 & 25.71 & 5.15 & 98.88 & 99.15 \\
\hline Mean \pm S. D. & & & & & $99.62 \pm 1.66$ & $100.05=1.42$ \\
\hline
\end{tabular}

The assay results (Table 6), expressed as the percentage of the label claim were found to be $94.10-104.50 \%$ for SMZ and 95.17$106.80 \%$ for TMP. These results were in good agreement with the content of SMZ and TMP in the powder mixtures, according to the United States Pharmacopoeia requirements (93.00$107.00 \%$ ) for solid preparations (quantified by HPLC) (3). Satisfactory multivariate calibration models can be obtained when mean errors in concentrations between the reference and proposed methods lie in the $\pm 5 \%$ to $\pm 10 \%$ range, with values under $\pm 2 \%$ proving ideal. This way, the assay results were compared using Two One-Side $t$ Test (TOST) and twentyfive (twelve samples for SMZ and thirteen samples for TMP) presented no significant differences at $95 \%$ confidence level. The only exception was between the result of HPLC versus $\mathrm{UV}$ for SMZ in real sample 3 (Table 6). 
These results clearly show that the achievement of low prediction errors on real samples is possible as a consequence of the fact that the calibration set be representative of pharmaceutical formulation (quantitative composition of synthetic samples very similar to the real sample). For this sample 3, the quantitative compositions of the excipients present in the tablets may have influenced the results.

\section{Conclusions}

$p H$ selection combined with multivariate calibration can be considered as a potential resource to be exploited in pharmaceutical powder mixture analysis. The $\mathrm{pH}$ selection used in this work produced models with high predictive ability, and demonstrated the need to further optimize the method with regards to UV analysis combined with multivariate calibration. Furthermore, proposed method showed high selectivity under the conditions tested, low cost and low production of toxic waste.

\section{Acknowledgements}

The authors thank Pratti Donaduzzi Ltd. (Brazil) for samples supply and CNPq, Capes, Fapergs and ANVISA for financial support.

\section{Conflict of Interest}

The authors declare no conflict of interest.

\section{References}

1. Brunton L, Chabner B, Knollman B. Goodman and Gilman's The Pharmacological Basis of Therapeutics. Twelfith e. MacGraw-Hill; 2011.

2. ANVISA. Farmacopeia Brasileira. $5^{\circ}$. Brasília; 2010.

3. United States Pharmacopoeial Convention. USP33-NF28. 33rd ed. Rockville: United States Pharmacopoeial Convention; 2010.
4. Adegoke OA, Babalola CP, Kotila OA, Obuebhor O. Simultaneous spectrophotometric determination of trimethoprim and sulphamethoxazole following charge-transfer complexation with chloranilic acid. Arab J Chem [Internet]. King Saud University; 2014; Available from: http://dx.doi.org/10.1016/j.arabjc.2014. 05.022

5. Medina JR, Miranda M, Hurtado M, Dominguéz-Ramírez AM, Ruiz-Segura JC. Simultaneous determination of trimethoprim and sulphamethoxazole in immediate-release oral dosage forms by first-order derivative spectroscopy: application to dissolution studies. Int $\mathbf{J}$ Pharm Pharm Sci. 2013;5(4):505-10.

6. López-Martinez L, López-de-Alba PL, De-Léon-Rodriguez LM, YepezMurrieta $M$ de L. Simultaneous determination of binary mixtures of trimethoprim and sulfamethoxazole or sulphamethoxypyridazine by the bivariate calibration spectrophotometric method. J Pharm Biomed Anal. 2002;30:77-85.

7. Goodarzi M, Shahbazikhah P, Sohrabi MR, Fathabadi M, Nouri SH. Direct orthogonal signal corretion-partial leas squares for simultaneous spectrophotometric determination of sulphamethoxazole and trimethoprim in pharmaceutical formulation and synthetic samples. J Chil Chem Soc. 2009;54(3):309-13.

8. Silva FEB, Ferrão MF, Parisotto G, Müller EI, Flores EMM. Simultaneous determination of sulphamethoxazole and trimethoprim in powder mixtures by attenuated total reflection-Fourier transform infrared and multivariate calibration. J Pharm Biomed Anal. 2009;49(3):800-5. 
9. Silva FEB, Ziech C, Dias YP. Quantitative Determination of Sulphamethoxazole and Trimethoprim in Powder Mixtures Using Raman Spectroscopy and PLS. Lat Am J Pharm. 2011;30(6):1216-20.

10. Alves LDS, Rolim LA, Fontes AF, Rolim-Neto PJ, Soares MFDLR, Sobrinho JLS. Desenvolvimento de método analítico para quantificação do efavirens por espectrofotomeria no UVVIS. Quim Nova. 2010;33(9):1967-72.

11. Bonfilio R, Araújo MB De, Salgado HRN. Development and validation of an UV-derivative spectrophotometric method for determination of glimepiride in tablets. J Braz Chem Soc. 2011;22(2):292-9.

12. Polonini HC, Santos FC dos, Vaz UP, Brandão MAF. Desenvolvimento e validação de método analítico para determinação do teor de sinvastatina em cápsulas magistrais. Quim Nova. 2011;34(3):516-9.

13. Borba PAA, Riekes MK, Pereira RN, Stulzer HK, Vecchia DD. Desenvolvimento e validação de um método analitico por espectrometria UV para quantificação de carvedilol. Quim Nova. 2013;36(4):582-6.

14. Mendez ASL, Cassol JPE, Camargo VB De, Malesuik MD, Garcia C V. Quantitative Determination of Paliperidone in OROS ${ }^{\circledR}$ Tablets by Deriva- tive Spectrophotometric Method - Application in Extraction and Comparison to HPLC. Curr Anal Chem. 2014;10(1):158-65.

15. Maggio RM, Rivero M a., Kaufman TS. Simultaneous acquisition of the dissolution curves of two active ingredients in a binary pharmaceutical association, employing an on-line circulation system and chemometrics- assistance. J Pharm Biomed Anal [Internet]. Elsevier B.V.; 2013;72:51-8. Available from: http://dx.doi.org/10.1016/j.jpba.2012.09 .022

16. Roggo Y, Chalus P, Maurer L, LemaMartinez C, Edmond A, Jent N. A review of near infrared spectroscopy and chemometrics in pharmaceutical technologies. J Pharm Biomed Anal. 2007;44:683-700.

17. Hegazy MA-M, Eissa MS, El-Sattar OIA, El-Kawy MMA. Determination of a novel ACE inhibitor in the presence of alkaline and oxidative degradation products using smart spectrophotometric and chemometric methods. J Pharm Anal. 2014;4(2):132-43.

18. Piantavini MS, Pontes FLD, Weiss LX, Sena MM, Pontarolo R. Comparison between Ultraviolet and Infrared Spectroscopies for the Simultaneous Multivariate Determination of Pyrantel and Praziquantel. J Brazilian Chem Soc. 2015;26(7):1387-95.

19. Cordeiro GA, Peralta-Zamora P, Nagata N, Pontarollo R. Determinação de misturas de sulfametoxazol e trimetoprima por espectroscopia eletrônica multivariada. Quim Nova. 2008;31(2):254-60.

20. Dohoda D, Tsinman K, Tsinman O, Wang H, Tam KY. Spectrophotometric $\mathrm{pKa}$ determination of ionizable pharmaceuticals: Resolution of molecules with weak pH-dependent spectral shift. J Pharm Biomed Anal. Elsevier B.V.; 2015;114:88-96. 